\title{
Study of Suspended Prosecution (Geschorst) in Geschil Prejudicial Dispute for Criminal and Civil Settlement in Indonesia
}

\author{
${ }^{1}$ Ketut Wira Hadiputra, ${ }^{2}$ Setiyono, and ${ }^{3}$ Kadek Wiwik Indrayanti \\ ${ }^{1,2,3}$ Master of Legal Science Postgraduate Program \\ University Of Merdeka Malang \\ Indonesia
}

\begin{abstract}
This article aims to examine the regulation of Prejudicial Geschil in investigating criminal cases, which involves a civil law element in the applicable laws and regulations, and the legal consequences of Prejudicial Geschil in criminal cases which involve civil law elements. The method used is a normative legal research method. The results show that Prejudicial rules in examining criminal and civil cases are regulated in the Criminal Code; Regulation of the Supreme Court Number 1 of 1956 concerning the Legal Relations between the Civil Court and the Criminal Court; Law Number 4 of 2004 concerning Judicial Power; Number 6 of 1992 concerning Settlement of Cases in the High Court; Supreme Court Decision Number 413 K/Kr/1980 dated August 26, 1980, and Number 129K/Kr/1979 dated April 16, 1980; and Supreme Court Decision Number 628 K/Pid/1984 dated July 22, 1985. Legal consequences of Prejudicial Geschil in criminal and civil cases where criminal cases are suspended until given verdict in the civil cases. Then the legal implications of Prejudicial Geschil in Police Investigations are that the investigation process is temporarily suspended/pending, as has been regulated in Article 81 of the Criminal Code and the Supreme Court Regulation Number 1 of 1956 concerning the Legal Relations between the Civil Court and the Criminal Court.
\end{abstract}

Key words: Prosecution, Geschorst, Prejudicial Gechil, Criminal Case, Civil case.

\section{INTRODUCTION}

During the settlement process of a case that contains criminal and civil elements, generally, the criminal case process will temporarily be suspended until the civil case is decided and obtained a permanent decision as stipulated in the provisions of Article 81 of the Criminal Code, Number 1 of 1956 and Number 4 of 1980.

The regulation regarding Prejudicial has been regulated in the Regulation of the Supreme Court Number 1 of 1956, which states that. In contrast, in the examination of a criminal case, there is a civil matter that needs to be settled on an issue or regarding a legal relationship between two certain parties, the examination of the criminal case may be suspended to wait for a court decision in the study of the civil case concerning civil rights. The provision of Number 1 of 1956 provides legal consequences for the criminal case process to be temporarily suspended to wait for Eintracht's verdict for the civil case. A prejudicial dispute (Prejudicial geschill) is a judicial dispute that arises between a criminal court and a civil court, and the one which must be resolved first is the civil case. At the same time, the criminal prosecution is temporarily suspended because before the trial can proceed, there is still a legal dispute that must be decided first by the authority. During the suspension, the expiration period is also suspended, and this legal dispute is commonly known as a prejudicial dispute. ${ }^{[1]}$

According to ${ }^{[2]}$ the suspension of the expiry period takes effect when there is a Prejudicial geschil that raises issues regarding the court's authority or when a dispute arises during the settlement of a criminal case because other different sources must try the case. On the other hand, the suspension of the expiration period does not occur in legal disputes that negate punitive measures as regulated in Article 323 BW, the last paragraph of Article 241 of the Procedure of Criminal Code, and the application of Article 16 of the Procedure of Criminal Code. Simmons argues that the expiration period is not considered during the break-in, a suspension or postponement of the expiration period. If the rest has expired, the period of expiry that previously existed will also be considered in the new expiry period. For example, in a dispute of heirloom, suddenly there is a report of the embezzlement of artifact even though the property is not or has not been declared as an heirloom, the criminal process must be suspended 
(gheschorst) first until there is a decision regarding the certainty of being an "heirloom" or not. If it is proven that the embezzled property is not included as an heirloom, the criminal process must be terminated with SP-3 procedure (Warrant for Termination of Investigation). ${ }^{[3]}$

Based on the above case, several issues are being studied, namely examining the regulation of Prejudicial Heschel in reviewing criminal and civil cases in the legislation, then checking the legal consequences of Prejudicial geschil in police investigations.

\section{RESEARCH METHODOLOGY}

This study uses a normative legal research method (legal research) ${ }^{[4]}$ which is a distinctive character of law as science (jurisprudence) ${ }^{[5]}$, since what is being studied is about suspended prosecution (geschorst) in Prejudicial geschil disputes to settle criminal and civil cases. There are three types of approaches used: statute approach, conceptual approach, and case approach.

\section{DISCUSSION}

The regulation of Prejudicial Geschil in examining criminal and civil cases in Indonesia is regulated in various codes, namely:

3.1 Article 81 of the Criminal Code stipulates that: suspension of criminal prosecution develops in the presence of a judicial dispute and may suspend expiration period. If scrutinized, it seems that the provision of Article 81 of the Criminal Code states that the prosecution is temporarily suspended because there is a judicial or prejudicial dispute, which means a period for stopping prosecution, namely civil law disputes that must first be settled before the criminal proceedings can proceed.

3.2 PERMA Number 1 of 1956 concerning Legal Relation between the Civil Court and the Criminal Court: The judicial dispute is not regulated, so there is a legal void regarding Prejudicial geschil. This gives rise to dualism in judicial practice in Indonesia. On the one hand, judges postpone the examination of civil cases before a criminal decision has permanent legal force. On the other hand, some judges prioritize examining civil cases, thereby deferring the study of criminal cases. ${ }^{\text {[6] }}$

To patch the legal void and provide more detailed guidelines for Prejudicial geschil, Number 1 of 1956 has provided guidelines for judges, which are basically as follows: a) Provide direction regarding methods of resolving criminal cases (Article 1): an examination of criminal cases can be suspended or postponed; b) The suspension of criminal examination can be terminated at any time (Article 2); c) Judges that examine a criminal case which related and contains Prejudicial geschil with the civil case are not bound by the civil decision regarding whether there is or not civil rights relating to the criminal case (Article 3).

3.3 Circular Letter of the Supreme Court Number 4 of 1980 concerning Article 16 of Law Number 14 of 1970 and Prejudicial Geschil. Regarding "Prejudicial geschil," it is stated that: (1) There some of "Prejudiciel geschil" as a "question prejudicial an I' action" and there are some as "question prejudicially au judgment." (2) "Question prejudicial an I' action" is regarding certain criminal acts referred to in the Criminal Code (among others Article 284 of the Criminal Code). (3) In this case, the civil provisions shall be decided before the criminal prosecution is decided. (4) "Question prejudicially au judgment" concerns the issues regulated in Article 81 of the Criminal Code. The article only gives authority, not the obligation, to the criminal Judge to suspend the examination, waiting for the decision of the civil Judge regarding the dispute. (5) Attention is requested if a judge wishes to use this legal institution. The criminal Judge is not bound by the decision of the concerned civil Judge, as stated in No. 1 of 1956.

3.4 Circular Letter of the Supreme Court Number 6 of 1992 concerning Settlement of Cases in High Courts and District Courts. Taking into account the dated August 4, 1969 Number 8 of 1969 concerning monthly reports and accountability for cases whose files were completed, and dated August 26, 1969 Number 12 of 1969 concerning the settlement of criminal and civil claims for which appeals were made, it turns out that until now the territory of criminal and civil cases, both those examined in the District Court and the High Court, takes excessive time and the ministering of the matter is not immediately resolved.

\subsection{Other Jurisprudences related to Pre Judicial Dispute (Prejudicial Geschil)}

Some of Jurisprudences related to Pre Judicial Disputes (Prejudicial geschil) are as follows:

Supreme Court Decision Number 413 K/Kr/1980, dated August 26, 1980: Judges' Considerations in Supreme Court Decision Number $413 \mathrm{~K} / \mathrm{Kr} / 1980$, dated August 26, 1980: If what is meant by the cassation prosecutor/defendant is "question prejudicially au judgment" as stated in Article 81 of the Criminal Code, then this only gives authority in this criminal case, which the Judge does not use power and not giving the Judge a legal obligation to wait for the decision from the civil Judge regarding the dispute; Whereas furthermore, Judges based on Supreme Court Regulation Number 1 of 1956, are not bound by a civil case decision regarding the existence or absence of a civil right. 
Supreme Court Decision Number 129K/Kr/1979 dated April 16, 1980. The legal abstraction states: because the examination at the district court has continued and collided with Prejudicial geschil regarding land ownership rights, it cannot be given a decision in the form of not accepting the claim or a decision in the form of escaping all lawsuits and what should be taken are: 1) "Suspend the trial until the civil judge determines who has the right to the land by giving the defendant a certain time to file a civil lawsuit"; or 2) "The case is decided by a criminal judge based on the evidence in the criminal examination";

Supreme Court Decision Number 628 K/Pid/1984 dated July 22, 1985 : "The High Court, before deciding on the subject matter of this case, should wait for the court's decision which will determine the ownership status of the land and the house with the decision." In this decision, it was stated: "Ordered the Bandung High Court to reopen the trial, and examine and decide on the subject matter of this case after the court decides for the civil case which will determine the ownership status of land and Building Utilization Rights Number 197/Penaragan which located at Jalan Merdeka Number 11A Bogor has a decision." Prejudicial disputes (Prejudicial Geschil) are adjudicating conflicts that arise between criminal courts and civil courts, and the one that must be settled first is the civil issue.

The reciprocal relationship between criminal and civil cases makes judicial disputes challenging to avoid for legal matters related to both. Sometimes, the object of the possibility that becomes the basis for prosecution in a criminal trial is the object of dispute in civil cases that demand to be resolved first, so that to obtain decisions that can guarantee legal certainty and justice, it is essential to pay attention to whether the object of the case is free from dispute or vice versa.

The reality of such formal law has the potential to violate the principle of bis in idem, which allows for two processes of examination and trial of a case against the same object at the same time. The focus of bis in idem is related to the principle of res judicata pro veritate habetur, namely the code that determines that what is decided by a judge must be considered correct unless there is a higher judge's decision that cancels the decision. The principle of res judicata pro veritate habetur means that what is decided by the Judge must be considered correct and assumed that the decision sentenced by the Judge had been going through the proving process of evidence at trial ${ }^{[7]}$. The principle of nebis in idem is a general principle that applies not only in civil cases but also in criminal cases and state administrative cases. In civil cases, the focus of nebis in idem is reflected in the provision of Article 1917 of the Civil Code, which states: "The power of a judge's decision that has obtained definite legal force is only regarding the subject matter in question." To use that power, the question demanded must be the same, the claim must be based on the same reason, and the case must be submitted by the same party and against the same parties in the same relationship.

Meanwhile, the provisions of Article $134 \mathrm{Rv}$. states: "Cases that have previously been submitted before a judge, by other parties concerning the same subject matter, or which by the same parties regarding the same subject matter have been submitted for settlement to the referees and are still ongoing, or In the case of a dispute which is closely related to a case that is already in the examination of another judge or is in the hands of the referees, it may be requested that the case be transferred to the other judge or to the referees who have been appointed, this condition must be conducted under a reasoned request before the defense is carried out on the day that has been determined for the defense."

The provisions of Article 1917 of the Civil Code in conjunction with Article $134 \mathrm{Rv}$ in conjunction with Article 76 of the Criminal Code means that for a case which at one time has been decided by a judge and has obtained permanent legal force (Eintracht von gewijsde), it may not be resubmitted. Therefore, if the case for the same claim is being resubmitted to the court, the Judge must reject the lawsuit.

\section{Legal Consequences of Prejudicial Geschil in Criminal and Civil Cases}

Based on the results of the study, it was found that in a case that started in 2018, Defendant 1 by the name Adji Zulkifli Bin Adji A'adin Amir in early 2003 came to the Plaintiff while condemning pleading to the Plaintiff, asking for help to lend the Plaintiff's land sized: $4 \mathrm{~m}$ x $8 \mathrm{~m}$ for building purpose to operate a Coffee Shop which would solely be used by the Defendant's mother (Mrs. Sa'adin Amir) to run the business. On a humanitarian basis and goodwill to help the Defendant and their family, Plaintiff built a coffee shop measuring $4 \mathrm{~m}$ x $8 \mathrm{~m}$ without any rent/payment. However, since Defendant Adji Zulkifli bin Adji Sa'adin Amir occupied the building measuring 4 MX 8 m together with Defendant 2 by the name Adji Alfian Bin Adji Sa'adin Amir, without notification and permission from the Plaintiff, they have erected buildings on the land belonging to the Plaintiff which the Plaintiff owns, then leased the premise to other parties. Even part of the land belonging to the Plaintiff has been sold or transferred to other third parties, among others, to Rahmadi as the owner of Aluminum Glass Store Azra, Sunarso as the owner of food stalls MA'E, food stalls Blambangan, as well as leasing/taking tariff from the pier for rental of mooring ships.

Another case with Plaintiff by the name M. Jos Soetomo, suing Defendant 1 by the name Adji Zulkifli and Defendant 2 by the name Adji Alfian to the police, with Police Report Number: LP/127/III/2018/POLDA KALTIM/SPKT I dated March 13, 2018, which was followed up with Investigation Order Number: Sp.Sidik/101/Res.1.2/VIII/2018/Ditreskrimum, dated 28 August 2018, 
Sp.Sidik/101/VIII/Res1.2/2018/Ditreskrimum and Investigation Order Letter Number: Sp.Sidik/101.a/ Res.1.2/X/2020/Ditreskrimum, dated 27 October 2020. In the investigation process, the Defendants by the name Adji Zulkifli and Adji Alfian has been deemed sufficient by the investigator to meet the condition as suspected of violating Article 385 paragraph (4) of the Criminal Code, and Investigators then transferred the Criminal case file to the East Kalimantan High Prosecutor's Office CQ. General Crime Assistant. East Kalimantan High Prosecutor's Office cq. General Crime Assistant, reject the case file as recorded in Letter Number: B-706/O.4.4/Eku.1/04/2021 dated April 9, 2021, regarding the reversion of case files on behalf of Suspects Adji Zulkifli Bin Adji Saadin Amir and Adji Alfian Bin Adji Saadin Amir. They are suspected of violating Article 385 paragraph (4) of the Criminal Code to complete the file (P-19).

The letter provides formal and material instructions to investigators regarding the case file. At the end of the proper education, it is stated that since this criminal case is currently undergoing a civil lawsuit at the Samarinda District Court carried out by the two suspects, the criminal process against them is temporarily suspended for waiting for an Eintracht decision on the civil case, as regulated in Article 81 of the Criminal Code, Number 1 of 1956 and Number 4 of 1980.

Based on the provisions on Prejudicial geschil in Number 4 of 1980 above, the court in its decision gave an opinion that the issue of the ownership status of oil palm plantations in Lot 1255 and 1256, in this case, was not a "question prejudicial an I'action" because it was not stated in the Criminal Code, but only a "question prejudicially au judgment" concerning the issues regulated in Article 81 of the Criminal Code, where the article only gives authority, no obligation to the Criminal Judge to suspend the examination.

\section{Legal Consequences of Prejudicial Geschil in Police Investigation The Criminal Judicial is Suspended for Civil Decision}

If the report or criminal process depends on the civil process currently proceeding in the court, the criminal procedure must wait for the decision on the civil dispute. For example, regarding inheritance disputes, suddenly, there are reports of embezzlement of inheritance even though the property is not or has no clear status as an inheritance. The criminal process must be suspended until there is a decision regarding the certainty of 'inheritance' or not. If what is sold is proven not to be inherited property, the criminal process must be terminated with SP-3 (Warrant for Suspension of Investigation) ${ }^{[8]}$. In criminal cases in which there is a civil dispute, it is not unusual if a dispute which falls into the field of civil law is then brought into the area of criminal law. Investigators are the front gate in enforcing criminal law in Indonesia before proceeding or determining suspected criminal cases with civil elements or issues. It is only natural that they first study all matters related to the reported legal facts to provide justice for all parties ${ }^{[9]}$.

Therefore the suspension of a criminal offense waiting for a civil decision is a form of justice in the same freedom, namely freedom of opinion and expression (freedom of speech and presentation). On the other hand, it provides equal rights and opportunities for the broadest fundamental freedoms as wide as the same freedoms for everyone, both in civil and criminal matters. Postponing the examination of criminal cases is a concept by the Regulation of the Supreme Court Number 1 of 1956 concerning the Relation of Criminal and Civil Cases.

The essence of Supreme Court Regulation Number 1 of 1956 is not to cause hesitation for judges to decide criminal cases, but during examination in the trial process, facts were found that there was a civil dispute in the criminal case. This regulation is used as a guide for judges in issuing interim decisions to postpone criminal cases until civil cases have permanent legal force within a period of expiration (article 81 of the Criminal Code). The postponement of the examination of criminal cases is carried out so that civil lawsuits that arise when the criminal law process is carried out can be resolved first. This is because civil law decisions as private law can affect illegal law decisions as public law and not vice versa.

A decision in a civil case sought in a civil case examination is sufficient on a mere formal basis. Meanwhile, the conclusion of a criminal case reflects the material truth or the absolute truth because what is sought in the process of examination and trial of criminal cases is the actual truth. The material fact obtained from the study of criminal cases will influence and determine the position of the civil case, not the other way around. The role of these two cases is that the decision of the criminal case will determine the civil case. If Defendant is acquitted, it proves the civil agreement materially.

On the other hand, if the decision in a criminal case convicts Defendant Eintracht van gewijsde, then the decision proves that the formal truth in the civil decision is contrary to the fact. Decisions in criminal cases have the function of canceling decisions in civil cases. Therefore, it is used as an excuse to file a legal action against a civil case decision. Based on Article 76 of the Criminal Code, it is inevitable that the Eintracht van gewijsde decision is the criminal case decision, not the civil case decision. So the main requirement for a criminal case decision to be nebis in idem is if an Eintracht van gewijsde decision has decided the act (in a criminal action). Against the conclusion of the criminal case may not be prosecuted for a second time. The purpose and 
background or ratio of the establishment of this provision are for or for the sake of legal certainty and justice, where a defendant who has been sentenced to a permanent decision may not be allowed by the state to continue to carry out criminal prosecutions ${ }^{[10]}$.

Based on Article 76 of the Criminal Code, that an act cannot be prosecuted more than once (nebis in idem), is against the same act of a criminal act that has been examined and decided by the court with a verdict (the three kinds of orders) that have been settled (Eintracht van gewijsde zaak). Decisions on civil cases cannot be used as the basis to be nebis in idem for criminal cases, which are now being examined at all levels.

The reason and logic in the provisions of Article 76 of the Criminal Code are that a civil case decision only reflects the formal truth and does not reflect the material truth or the actual truth because the fact sought in the examination of civil cases is sufficient on legal validity. Meanwhile, the decision of a criminal case reflects the material reality. This is also the background for issuing the Regulation of the Supreme Court of the Republic of Indonesia Number 1 of 1956 concerning the Relations between the Civil Court and the Criminal Court. In Article 3, it is expressly stated that "a court decision does not bind the court in examining criminal cases in a civil examination regarding the existence or absence of a civil case."

Based on the East Kalimantan High Prosecutor's Office CQ's. General Crimes Assistant in Letter Number: B706/O.4.4/Eku.1/04/2021 dated April 9, 2021, regarding the reversion of case files on behalf of Suspects Adji Zulkifli Bin Adji Saadin Amir and Adji Alfian Bin Adji Saadin Amir who are suspected of violating Article 385 paragraph (4) of the Criminal Code as the file is required to be completed (P-19). The letter provides formal and material instructions to investigators regarding the case file, which at the end of the proper education it is stated that because this criminal case is currently undergoing a civil lawsuit at the Samarinda District Court carried out by the two suspects, the criminal process against them is temporarily suspended to wait for an Eintracht decision for the civil case as regulated by Article 81 of the Criminal Code, Based on the provisions of Prejudicial geschil in No. 4 of 1980 above, the court in its decision gave an opinion that the issue of ownership of oil palm plantations in Lot 1255 and 1256, in this case, was not a "question prejudicial an I'action" because it was not stated in the Criminal Code, but only a "question prejudicially au judgment" concerning the problems regulated in Article 81 of the Criminal Code, where the article only gives authority, not an obligation to the Criminal Judge to suspend the examination, awaiting the decision from the Civil Judge. Therefore, the relations and reciprocal position between the two cases (civil and criminal) is that the material truth obtained from the examination of criminal cases will influence and determine the part of the civil case, not the other way around. Thus, the position of these two cases is that the decision of the criminal case will determine the conclusion of the civil case ${ }^{[11]}$.

The relations between a civil case and a criminal case must be distinguished between the issue of nebis in idem in Article 76 of the Criminal Code and the issue of a Prejudicial geschill dispute in Article 81 of the Criminal Code. They cannot be mixed. The problem of nebis in idem is that it can no longer be prosecuted for an act in a crime that has been decided by a permanent decision, as in the reason for the investigator who wants to stop the investigation in this criminal case. At the same time, the existence of a judicial dispute is a matter of temporarily halting the prosecution by a judge in court because there is a judicial dispute with other cases that can occur in terms of having something to do with other issues (can be criminal or civil) which have been examined first but have not been decided. The nature of the relations between the two cases is only practical and does not close the prosecution rights for criminal cases. However, based on the Regulation of the Supreme Court of the Republic of Indonesia Number 1 of 1956, the criminal Judge does not need to consider the civil case in the case of a judicial dispute with a civil suit. This is by the notion of judicial disputes according to Article 81 of the Criminal Code, which was initially intended solely as the right of the judges, where judges are obliged to stop prosecuting criminal cases by waiting for the civil case to be decided first ${ }^{[12]}$.

\section{CONCLUSION}

Regulation of Prejudicial geschil in examining criminal and civil cases in the applicable laws and regulations include the following: a) the Criminal Code; Article 81 of the Criminal Code Temporarily suspend prosecution due to a judicial or prejudicial Dispute; b) Supreme Court Regulation Number 1 of 1956 concerning Legal Relations Between Civil Court and Criminal Court; c) Circular Letter of the Supreme Court Number 4 of 1980 concerning Article 16 of Law Number 14 of 1970 (with the enactment of Law Number 4 of 2004 concerning Judicial Power, juncto Law Number 14 of 1970 concerning Basic Provisions of Judicial Power as has been amended by Law Number 35 of 1999 concerning Amendments to Law Number 14 of 1970 which declared invalid) and Prejudicial Geschil; Prejudicial geschil contains the "Question prejudicielle a I' action" which is about certain criminal acts referred to in the Criminal Code; and the "Question prejudicielle au jugement" concerning the authority, not the obligation, for the Criminal Judge to suspend the examination, to wait for the decision of the Judge regarding the Civil dispute; d) Supreme Court Circular Number 6 of 1992 concerning Settlement of Cases in High Courts and District Courts; cases in the District Court or in the High Court can already be resolved within 6 months and certain cases are possible to settle in more than 6 months, the Head of the District Court or High Court is required to report the matter by mentioning the rationale to the Head of the High Court and the 
Chief Justice of the Supreme Court of the Republic of Indonesia; e) Other jurisprudence related to Prejudicial Geschil among others; Supreme Court Decision Number 413 K/Kr/1980, dated August 26, 1980: Supreme Court Decision Number 129K/Kr/1979 dated April 16, 1980; and Supreme Court Decision Number 628 K/Pid/1984 dated July 221985

The legal consequences of Prejudicial Geschil in criminal and civil cases in police investigations. The legal consequences of Prejudicial Geschil in criminal and civil cases include the following: Criminal Cases are suspended to wait for Civil Decisions, Suspension of examination of criminal cases, and decisions of civil cases cannot be used as the basis for nebis in idem for criminal cases that being examined at all levels. b) The legal consequence of Prejudicial Geschil in Police Investigations is that the investigation process is temporarily suspended/ postponed, as has been regulated in Article 81 of the Criminal Code and Supreme Court Regulation Number 1 of 1956 concerning the Legal Relations between the Civil Court and the Criminal Court.

\section{SUGGESTION}

Some suggestions that can be proposed include the following:

The existence of Supreme Court Regulation that has the characteristics of public binding or is related to other bodies needs to be intensively socialized so that in its application by law enforcement officials it does not become multi-interpreted or wrong, especially regarding the position in Law Number 12 of 2011 which replaces Law Number 10 of 2004 concerning the Legal Drafting.

Prejudicial Geschil contains "Question prejudicially au judgment" concerning the authority, not the obligation, for the Criminal Judge to postpone the examination and wait for the Judge's decision regarding the civil dispute. In this case, the Judge's discretion is needed in dealing with Prejudicial Geschil.

\section{REFERENCES}

1. R. Soesilo, The Criminal Code (KUHP) and its Complete Comments Article by Article, Bogor: Politea, 1994 , page 942.

P.A.F. Lamintang, D. Simmons. 1992. Book of Criminal Law Study. Bandung: Pioneer Jaya. page 374

3. A.F. Lamintang, D. Simmons. 1992. Book of Criminal Law Study. Bandung: Pioneer Jaya. page 372

4. Peter Mahmud Marzuki, Legal Research, Jakarta: Prenada Media, 2008, page 29

5. J.J. Brugink, Rechtsreflecties, Translated by Arif Sidartha, Bandung: Citra Aditya Bakti, 1995, pages 213-218

6. Asep N Mulyana, Deferred Presecution Agreement in Business Crimes, Jakarta: PT. Grasindo, page 85

7. E.N. Butarbutar, Wealth Law According to the Systematics of the Civil Code and Its Development, Bandung: Refika Aditama, 2016, page 97

8. Melisa Ifityanti. 2010. Juridical Analysis of the Authority of Investigators Issuing Orders to Terminate Investigations (SP-3) on Corruption Crimes. Medan : Law Faculty of North Sumatra University

9. John Thamrun. Prajudicial Disputes. Jakarta: Sinar Graphic. 2016. page 85

10. Zainal Abidin, 2005. Sentencing, Crime and Action in the Draft Criminal Code. ELSAM, Jakarta. page 18-1

11. A. Ridwan Halim, 1982. Criminal Law and Questions and Answers. Jakarta: Ghalia Indonesia, page 31

12. R. Soeroso. 1993. Introduction to Law. Jakarta: Sinar Graphic. page 269 